\title{
LEXICAL MEANS OF CONSTRUCTING IMAGES OF GODLINESS DEVOTEES IN HAGIOGRAPHIC TEXTS ${ }^{1}$
}

\author{
Evgeniya G. Dmitrieva \\ Volgograd State University, Volgograd, Russia \\ Irina A. Safonova \\ Volgograd State University, Volgograd, Russia
}

\begin{abstract}
The article provides some results of linguistic analysis carried out on biographies of female godliness devotees, that focuses on linguistic representation of culturally significant concepts and moral values of ethnos with religious-and-moral ideals as their central component in hagiographic texts of the $18^{\text {th }}-$ $19^{\text {th }}$ centuries. The authors point to the lexical units which belong to two semantic groups: the emotives and perceptives. To create the images of female godliness devotees, the units comprising each of the abovementioned lexical sets are used in a particular way, revealed by the authors. It has been stated, that specific character of emotive vocabulary use in hagiographic texts depends on its functional impact, with characterological function recognized as the major one. The emotive lexical units, regarded as key characteristics, contribute significantly to plot development and genre canonical structure realization. The criteria for selecting lexical units with semantics of perception as well as their pattern of use are determined by the language system peculiarities and existing concept of religious devotion. The paper reviews linguistic means of perceptional processes explication that are significant for describing godliness devotees. The research results establish the dominance of visual perception as a process that determines female devotees' interaction with the real world and the world beyond reality disclosed to them by the will of the God, (which is reflected in the direct meanings of linguistic units), as well as revealing a connection with mental activity (reflected in the figurative meanings of linguistic units).

Key words: hagiography, godliness devotee image, emotive vocabulary, perceptional vocabulary, lexical semantics, functioning.

Citation. Dmitrieva E.G., Safonova I.A. Lexical Means of Constructing Images of Godliness Devotees in Hagiographic Texts. Vestnik Volgogradskogo gosudarstvennogo universiteta. Seriya 2. Yazykoznanie [Science Journal of Volgograd State University. Linguistics], 2019, vol. 18, no. 4, pp. 75-87. (in Russian). DOI: https:// doi.org/10.15688/jvolsu2.2019.4.6
\end{abstract}

УДК 81'37:26-246/-247

Дата поступления статьи: 14.05.2019

ББК 81.053 .1

Дата принятия статьи: 03.09.2019

\section{ЛЕКСИЧЕСКИЕ СРЕДСТВА СОЗДАНИЯ ОБРАЗОВ ПОДВИЖНИЦ БЛАГОЧЕСТИЯ В АГИОГРАФИЧЕСКИХ ТЕКСТАХ ${ }^{1}$}

\author{
Евгения Геннадьевна Дмитриева \\ Волгоградский государственный университет, г. Волгоград, Россия \\ Ирина Александровна Сафонова \\ Волгоградский государственный университет, г. Волгоград, Россия
}

Аннотация. Статья посвящена проблеме языкового воплощения в агиографических текстах культурно значимых смыслов, ценностных ориентиров этноса, центральным из которых является понятие религиозно-нравственного идеала. Материалом для изучения послужили жизнеописания подвижниц благочес- 
тия XVIII-XIX веков. В центре внимания авторов находятся лексические единицы двух семантических групп - эмотивы и перцептивы. Установлены особенности, определяющие употребление единиц каждого из названных лексических множеств для создания образов подвижниц. Показано, что специфика использования эмотивной лексики в агиографическом тексте задается ее функциональной нагрузкой: в качестве основной функции признается характерологическая. Эмотивы входят в число «ключевых характеристик», играют важную роль в развитии сюжета и реализации жанрового канона. Отбор и специфика функционирования единиц с семантикой восприятия детерминируются особенностями языковой системы и существующими представлениями о подвижничестве. Рассмотрены средства языковой экспликации перцептивных процессов, значимых для описания подвижниц благочестия. Установлено доминирование зрительного восприятия как процесса, определяющего взаимодействие с реальным миром и миром, находящимся за границами реальности и открывающимся подвижницам по воле Господа (отражено в прямых значениях языковых единиц), а также обнаруживающего связь с мыслительной деятельностью (отражено в переносных значениях языковых единиц).

Ключевые слова: жизнеописание, образ подвижницы, эмотивная лексика, перцептивная лексика, лексическая семантика, функционирование.

Цитирование. Дмитриева Е. Г., Сафонова И. А. Лексические средства создания образов подвижниц благочестия в агиографических текстах // Вестник Волгоградского государственного университета. Серия 2, Языкознание. -2019. - Т. 18, № 4. - C. 75-87. - DOI: https://doi.org/10.15688/jvolsu2.2019.4.6

\section{Введение}

Отечественные подвижники благочестия всегда занимали значительное место в сознании русского народа: почитались их святость, неутомимое служение людям. Память о праведниках поддерживалась контактами с подвижниками, устной традицией и бытованием в агиографической литературе (об этом подробнее см.: [Буганов, 2009]).

Агиографический жанр долгое время являлся одним из самых распространенных в русской книжности, имел большое значение для формирования христианского мировоззрения [Творогов, 2005, с. 3], на протяжении веков оставаясь важнейшим средством поддержания культурной памяти русского народа. В.В. Красных, ссылаясь на Я. Ассмана, понимает культурную память как форму «трансляции и актуализации культурных смыслов», которая создает и воспроизводит идентичность сообщества, а также как некое знание, регулирующее деятельность человека и управляющее переживаниями, действиями, всей жизненной практикой людей в рамках общения и взаимодействия в социальных группах и в обществе в целом [Красных, 2016, с. 132]. Центральное место среди ключевых культурных смыслов занимают представления о нравственном идеале.

При общей определенности ядра понятия нравственного идеала (см., например: [Воловикова, 2004; Иконникова, 1962; и др.]) в научной литературе предпринимались попытки разграничить его типы с опорой на различия в источниках тех морально-этических принципов, которым нужно следовать. Так, выделяется понятие религиозно-нравственного идеала и возникает необходимость говорить о специфике религиозно-этических принципов по отношению к морально-этическим принципам. Хотя различия между ними могут показаться несущественными, осмысление их через призму святости свидетельствует об исключительном характере религиозно-нравственного идеала [Дмитриева, 2018, с. 66].

В статье представлены результаты очередного этапа реализации проекта, ориентированного на изучение языковых средств создания нравственного идеала в разновременных агиографических текстах, поскольку именно святые своей жизнью воплощают нравственный идеал. Источниками для отбора фактического материала послужили жизнеописания подвижниц благочестия XVIII-XIX вв. (см. список источников) ${ }^{2}$.

В рассматриваемых текстах показаны разные пути обретения Божественной благодати (праведничество, иночество, молчальничество, преподобничество, старчество, юродство). Среди изучаемых жизнеописаний представлены пространные, повествующие о жизни подвижниц с рождения и до кончины (жизнеописание Сезеновской игуменьи Серафимы, в схиме Евфимии), и краткие, рассказываю- 
щие о каком-то периоде жизни (жизнеописание рабы Божьей Татианы). Однако в текстовой и речевой организации анализируемых жизнеописаний обнаруживается общность, обусловленная во многом реализацией в них единого религиозно-нравственного идеала. Так, можно выявить повторяющиеся сюжетные мотивы, например смирение (см. об этом: [Стародубцева, 2018]), проявляющееся в отказе от должностей и наград, подражание учеников и др.

В языковом воплощении общность исследуемых житий обнаруживается в использовании лексических единиц разных тематических групп как средств создания образов подвижниц. В статье сосредоточим внимание на лексических единицах со значением эмоций и восприятия.

\section{Эмотивные лексемы как средство характеристики подвижниц}

Важную роль в выражении религиознонравственного идеала в агиографическом тексте играет лексика эмоций, что обусловлено ее особой функциональной нагрузкой.

Как отмечалось нами ранее, эмотивные лексемы в житиях выполняют характерологическую и текстообразующую функции [Дмитриева, 2011, с. 46]. К факторам, определяющим специфику реализации характерологической функции, относятся: 1) статус характеризуемого субъекта (святой / обычный человек); 2) характер обозначаемой глаголом эмоции (положительная / отрицательная / нейтральная) и ее интенсивность (низкая / средняя / высокая); 3) причина эмоционального переживания.

Принятое в науке деление эмоций на положительные и отрицательные в житийных текстах теряет свою однозначность, поскольку положительные эмоции могут оцениваться отрицательно, а отрицательные - положительно. Так, традиционно чувство страха, испытываемое по отношению к Богу, характеризует добродетель, а от смеха, хотя он и является выражением положительных эмоций, следует воздержаться:

(1) Благочестивымъ своимъ видомъ, благоговъйнымъ стояніемъ во храмъ, крестнымъ знаменіемъ, поклонами, слезами и она невольно внушала страхъ Божій, который отъ нея не отступаль никогда. Разъ, когда келейная ея громко разсм'ялась, она подошла къ ней, перекрестила ее и сказала: «Христосъ съ тобою, Аннушка; нехорошо, другь мой, такъ см'яяться, да и нездорово» (ME, c. 144-145).

Усложнение эмоционального рисунка житий проявляется и в том, что одно и то же чувство по-разному оценивается в течение жизни подвижниц и перед их кончиной, ср.:

(2) Проводя земную жизнь свою во страх' Божіемъ, монахиня Елисавета сохраняла всегда въ сердц' и въ памяти своей мысль о смерти и т中мъ облегчала себъ переходъ изъ временной жизни въ в 'ъчную (МЕ, с. 147);

(3) ...она безъ страха переселилась въ в Һчность... (ME, с. 147);

(4) Но лицо ея оставалось неизм'\$нно: соблюдая молчаніе, она не допускала себя ни до одной улыбки радости, ни до слезы горя (ВМ, с. 203);

(5) Предъ кончиною ея лицо осв'Ттила радостная улыбка, какой никогда не видали у нея при жизни (BM, с. 207).

Особенность в употреблении эмотивных лексем в исследуемых житиях проявляется в выражении ими высокой интенсивности эмоционального переживания. Как и в текстах более ранних периодов, для ее передачи используются единицы, обозначающие сильные эмоции и чувства, и разнообразные контекстуальные уточнители:

(6) Тогда великою радостію возсіяло лицо старицы, и она испустила духъ (ИМ, с. 15);

(7) Какъ велика была ея в'ъра и какъ глубока ея любовь, давшія ей такую энергію и настойчивость въ д $\mathbf{k} л \mathbf{k}$, не приносившемъ лично ей ничего, кром' лишеній! (РБТ, с. 17);

(8) Я съ величайшимъ и радостнымъ удовольствіемъ жертвовалъ ей н'ъсколько, хотя и занятыхъ, часовъ, дабы продлить ея присутствіе у меня... (СП, с. 278);

(9) Да и нельзя было не прильпиться всњмъ сердцемъ къ этой благочестивой старушк中, - съ какой стороны ни разсматривать ее (СП, с. 278).

В этой связи представляет интерес употребление лексемы любвеобильный«исполненный любви» (СЦСиРЯ, т. II, с. 273); «способный сильно любить или любить мно- 
гих» (БТСРЯ, с. 509). Если в современном русском языке данное прилагательное имеет скорее отрицательный оттенок, то в анализируемых текстах выражает положительную характеристику:

(10) Впрочемъ, кроткая и любвеобильная Марөа не приняла на себя должности постоянной надзирательницы и настоятельницы этого собравшегося къ ней семейства дъвственницъ (ИМ, с. 13);

(11) Почти десять льть пробыла Ковригина въ Кронштадт $\mathbf{k}$, исполняя зав мимая старушка неудовольствовалась «сіяніемъ свłточа въ своемъ только градъね», - какъ говорила она, - а решилась побывать въ Петербург $\mathbf{k}$, «дабы и тамъ скорбные и нуждающіеся узнали олюбвеобильномъ помощник'ъ» (СП, с. 280).

Описывая жизнь подвижниц, автор подчеркивает любовь, которая повсюду их сопровождала:

(12) Она находила душевное уг twеніе въ дом' своего духовнаго отца, приходскаго священника о. Петра, любившаго ее (ИС, с. 174).

(13) «Вела себя она, говориль ея брать, сь отличною кротостію и богоугодно, пользуясь всеобщею любовію не только въ семействъ, но и отъ другихъ людей». Одушевленная такою любовію и кротостію нрава, Марөа-труженица, часто, тайно отъ матери и отъ родныхъ, исполняла работы слуг.. (ИМ, с. 11).

Частотное употребление лексем с семантикой любви, традиционно характеризующее тексты житий, с одной стороны, можно считать проявлением житийного канона, нацеленного на установление определенной эмоционально-нравственной атмосферы, особого «православного» мирочувствования. Устойчивости этой атмосферы, по мнению Б.И. Бермана, и способствовала устойчивость, неизменность житийного канона [Берман, 1982, c. 162]. С другой стороны, высокая частотность указаний на чувство любви связана с коренными особенностями национальной языковой картины мира, русской ментальности. Так, В.И. Шаховский, обращая внимание на то, что «наша аффективная жизнь связана с национальными (этническими) идеями», относит любовь к универсальным эмоциям [Шаховский, 2009, с. 34]. Тем не менее многие отечественные и зарубежные авторы в раз- ные эпохи и независимо друг от друга отмечают, как показал Т.Б. Радбиль, особый «вселенский» характер русского понятия «любовь» [Радбиль, 2010, с. 248].

Сопоставление разных текстов показало, что на фоне общей частотности лексем с корнем -люб- могут быть выделены повторяющиеся «ключевые характеристики» подвижниц в рамках отдельных житий. Например, такой характеристикой в жизнеописании инокини Маргариты (Марфы) является утешение:

(14) «Она такъ была счастлива, по выраженію ея брата, что очень многіе постоянно ходили къ ней за сов 'Ттами, либо съ просьбою ут'\$шенія въ скорби». И она обладала въ высшей степени даромъ сов'ъта и ут中шенія (ИМ, с. 11);

(15) «Когда и мне бывало огорченіе, разсказываль о себъ братъ, я всегда обращался къ покойной сестр'-ут中шительниц'» (ИМ, с. 11).

Лексемы с корнем -див- повторяются в жизнеописании игумении Евпраксии:

(16) Какъ игуменія, блаженная Евпраксія была дивно-мудрою (ИЕ, с. 249);

(17) Не разъ въ пути ей сопутствоваль дивный свњтъ... дивный столпь огненный спась ее оть ножа бъглаго солдата... (ИЕ, с. 252);

(18) Когда омывали т中ло почившей, оное дивно само собою оказалось въ сидячемъ положеніи (ИЕ, с. 255).

Следует отметить, что в роли «ключевых характеристик» могут выступать не только эмотивные лексемы. Так, мотив созидания, деятельности, труда настойчиво повторяется в жизнеописании первоначальниц Мензелинского Пророко-Ильинского женского монастыря игумений Евгении и Филареты:

(19) ДҺятельность этихъ двухъ труженицъ по устроенію обители такь тьсно связана... (ИЕиФ, с. 231);

(20) Но отшельницы не падали духомъ; оне усердно молились и еще усерднее трудились. А трудились он' едва-ли не бол'е всякаго рабочаго крестьянина... (ИЕиФ, с. 234);

(21) Память этихъ тружениць-первоначальниць благоговњйно чтится признательною обителію (ИЕиФ, с. 239).

По-видимому, такие устойчивые характеристики призваны способствовать индивидуализации описаний. 
Выявляя сквозные мотивы русской языковой картины мира, А.Д. Шмелев отмечает важность того, что «тема счастья в русской языковой картине мира неразрывно связана с темой любви» [Шмелев, 2005, с. 460]. Отражение этой идеи находим и в агиографических текстах:

(22) Неменьшую любовь и уваженіе постепенно пріобрьла Марөа и внғ своего семейства, въ городь. «Она такъ была счастлива, по выраженію ея брата, что очень многіе постоянно ходили къ ней за сов 中тами, либо с просьбою ут中шенія въ скорби» (ИМ, с. 11).

Эмоциональная палитра изучаемых текстов разнообразна и не ограничивается только повторяющимися, «ключевыми характеристиками». В текстах описаны и особые эмоциональные состояния, связанные с религиозными переживаниями:

(23) Съ какимъ-то особеннымъ религіозновосторженнымъ чувствомъ слушала Ковригина вечерню... (СП, с. 278).

Заслуживает внимания то обстоятельство, что важнейшие решения подвижницы и их близкие принимают, руководствуясь сердцем - чувствами, эмоциями:

(24) Родители Евөиміи, люди благочестивой жизни, сердцемъ своимъ чувствовали, что ихъ дочь назначена для жизни не мірской, а духовной (ИС, с. 174);

(25) Вмьсть съ Ефимомъ Моргачевымъ должна была отправляться и дочь ихъ Евөимія; но для нея это отправленіе было не по сердцу (ИС, с. 175);

(26) Оставалась посл'大дняя р'ъшительная минута, и въ эту-то роковую минуту Евөимія обратилась съ молитвою къ Создателю всяческихъ въ сосъдственной горниц中. Ея слезная молитва услышана: нев «не бойся»... (ИС, с. 175-176).

Это позволяет говорить, что эмоциональная лексика играет важную роль и в развитии сюжета повествования.

Таким образом, в текстах жизнеописаний отечественных подвижников благочестия XVIII и XIX вв. лексика эмоций используется для характеристики персонажей, участвует в реализации житийного канона и репрезентации важных элементов русской языковой картины мира. Все это свидетельствует о том, что эмоции являются одной из ключевых составляющих представления о религиозно-нравственном идеале.

\section{Перцептивные глаголы как средство описания подвижниц}

Образ подвижницы создается разными лексическими средствами, важными среди которых являются перцептивные глаголы, номинирующие процесс взаимодействия человека с окружающим миром - от простого, «нейтрального», получения информации о реалиях до «эмоционально окрашенного» восприятия сведений о действительности.

Глаголы восприятия мы рассматриваем как единицы, формирующие отдельную лексико-семантическую группу, которая входит всостав лексико-семантического поля 'действие' (см. об этом: [Семантика древнерусского глагола..., 2015, с. 242]).

Специфика перцепции как вида деятельности детерминируется несколькими факторами, к наиболее значимым из которых относятся активность / пассивность воспринимающего субъекта и канал получения информации. В связи с этим перцептивные глаголы анализируются нами с учетом их дифференциации по разным основаниям. Характер воспринимающего субъекта (активный / пассивный) обусловливает выделение глаголов непреднамеренного и преднамеренного восприятия. Канал получения информации определяет способ восприятия, который, в свою очередь, задает выделение подгрупп глаголов с общим значением восприятия, зрительного восприятия, слухового восприятия, обоняния, осязания и глаголов, обозначающих восприятие на вкус (подробнее об этом см.: [Cемантика древнерусского глагола..., 2015, c. 241-244]).

Для создания образов подвижниц в изучаемом материале используются глаголы с общим значением восприятия, глаголы зрительного восприятия и глаголы слухового восприятия. Употребление перцептивных глаголов в рассматриваемых жизнеописаниях обнаруживает сходства, которые проявляются 
в характере значения лексической единицы (прямое или переносное).

Глаголы с общим значением восприятия, не содержащие в семантике указания на канал получения информации об окружающем мире, обозначают «синкретичное» восприятие, которое всегда осуществляется пассивным субъектом. Эта подгруппа представлена лексемами чувствовать, перечувствовать, почувствовать, которые, функционируя преимущественно в описаниях физического состояния подвижниц, реализуют переносные значения. Например:

(27) Мъжду тłмъ, тьлесныя силы подвижницы сильно истощались. Марөа чувствовала этоть постепенный упадокъ силъ (ИМ, с. 14);

(28) Евөимія тотчась же почувствовала облегченіе, силы возвратились... (ИС, с. 174);

(29) Но, почувствовавъ облегченіе, каждый разъ [болящие] откладывали поҺздку... (СП, с. 281);

(30) Покойная почувствовала бользнь сь января м ъсяца 1906 года (СИА, с. 434).

В приведенных контекстах глаголы чувствовать, почувствовать употребляются в сочетании с существительными упадок (сил), облегчение, болезнь, а потому обозначают не получение информации с помощью органов чувств, а состояние субъекта, не являющееся результатом взаимодействия с окружающим миром.

Глагол перечувствовать, представленный единичным употреблением в жизнеописании игумении Серафимы (в схиме Евфимии), используется для описания смятения подвижницы:

(31) Много и очень много она [Евөимія] перечувствовала: разныя мысли см'нялись одна другою... (ИС, с. 176).

В данном случае рассматриваемый глагол реализует значение, связанное не просто с мыслительной деятельностью, но со сменой мыслительных операций (пере-). Актуализации этого значения способствует использование существительного мысль и глагола сменяться.

Глаголы зрительного восприятия могут обозначать непреднамеренное и преднамеренное восприятие, реализуя как прямые, так и переносные значения.
Непреднамеренное зрительное восприятие репрезентировано в изучаемых текстах лексемами видать (увидать), вид $\mathbf{k}$ (увид $\mathbf{k} т ь$ ), узр $\mathbf{k} т ь$.

Глагол видать (увидать) используется и при описании подвижниц, и при описании людей из их окружения (нередко в сочетании с частицей не). Например:

(32) ...и, приказавъ чрезъ Бирюкова бывшимъ для поливки деревъ женщинамъ спрятаться, чтобы не видали лица затворника... (ИС, с. 179);

(33) Среди многихъ вид'ній, какихъ удостаивалась блаженная, она часто видала древнюю инокиню Акилину... (ИЕ, с. 252);

(34) Когда пришли сестры и увидали Евдокію здоровою, умилились и прославили Бога (ИЕ, с. 248);

(35) Но какъ радостно забилось сердце у Ковригиной, когда она увидала впервые этого дивнаго пастыря за вечернею службою... (СП, с. 278).

Рассматриваемые глаголы используются в изучаемых текстах преимущественно для номинирования получения сведений о других людях, о чем свидетельствует сочетание с нарицательными существительными лиць, инокиня, пастырь и с антропонимом Евдокия.

Аналогичную тенденцию в употреблении обнаруживает глагол вид $\mathbf{k} m \mathbf{b}$ (увид $\mathbf{k} m \mathbf{b})$. Реализуя прямое значение, вид $\mathbf{k} m b$ (увид $\mathbf{k} m b)$ функционирует и в описаниях подвижниц, и в описаниях людей из их окружения. Например:

(36) Минуты кончины блаженной старицы Господу угодно было ознаменовать особеннымъ чуднымъ знаменіемъ, которое видъла неотлучно сид Свшая при ней сестра (Мавра) (ИМ, с. 15);

(37) ...смотрЊвшій изъ алтаря на приступавшихъ къ св. чаш' пом'щикъ М. вид'ль ее озаренною особымъ светомъ (ВМ, с. 201);

(38) ...eе [Ирину] видъли на молитвњ и въ башн $\mathbf{k}$, и въ колодц $\mathbf{k}$, и подъ церковью... (БИЗ, с. 230);

(39) Прежде всего на тьль почившей увид қли «жельззныя вериги» (ИМ, с. 15-16);

(40) ...вдругъ она... увид'ла, как ея келлія вдругъ открылась, и въ нее вошли два св мужа... (ИЕ, с. 248).

Преимущественно для создания образов подвижниц используется глагол узр $\mathbf{k m b}$, синонимичный в рассматриваемом материале увид $\mathbf{k m b .}$

(41) ЗатЊмъ сестра узрћла несказанной красоты юношу... (ИМ, с. 15); 
(42) За нъсколько времени до смерти блаженная... узрғла надъ собою распростертую десницу... (ИЕ, с. 252).

Употребление данного глагола в конструкции с существительными юноша, десниц, номинирующими реалии, получение информации о которых может осуществляться с помощью органов зрения, подтверждает обозначение им зрительного восприятия.

Глагол вид $\mathbf{k m b}$, обнаруживающий широкие сочетаемостные возможности, отмечен в рассматриваемых текстах в конструкциях с абстрактными существительными, например:

(43) Она [Апфія]... не обременяла жертвователей просьбами, напротивъ, когда вид'ла нужду у своего прежняго благодттеля, сама... помогала ему (СИА, с. 431).

Употребление вид $\mathbf{k m b}$ в сочетании с существительным нужда свидетельствует о невозможности обозначения им зрительного восприятия, важнейшим условием которого является конкретность воспринимаемого объекта. В приведенном контексте анализируемый глагол номинирует не процесс получения информации об окружающем мире, а мыслительный процесс.

Для обозначения ментальной деятельности глагол вид $\mathbf{k} m b$ используется также в следующем контексте:

(44) ....сердце ея предалось еще большей горести, видя влад'вльцами родного ея дома чуждыхъ для нея... (ИС, 177).

Такое употребление данного глагола отмечено только в описаниях действий подвижниц. Агиограф меняет «фокус», акцентирует внимание не на взаимодействии с окружающим миром, а на осмыслении происходящего в нем.

В исследуемых текстах глаголы непреднамеренного зрительного восприятия обнаруживают употребление, близкое современному и не отмеченное нами в других текстах, рассмотренных в предыдущих работах (см., например: [Дмитриева, Сафонова, 2018; Сафонова, 2019]).

Так, в жизнеописании старицы Параскевы находим:
(45) И вотъ мы видимъ: больные исц'Вляются; гр\$шные каются; вЊрующіе радуются сил' Божіей, въ мир' являющейся, и укр'ппляются... (СП, c. 285).

В данном случае приводится описание разных событий, происходящих в мире с верующими и неверующими людьми. Причем часть этих событий может быть воспринята зрительно (больные иси кляются), а часть нет (в врующіе радуются сил $\mathbf{k}$ Божіей и укр киляются). Это позволяет говорить о реализации глаголом вид $\mathbf{k m b}$ «обобщенного» значения, близкого современному «испытывать, переживать, а также встречать что-л., сталкиваться с чем-Л.» (МАC, т. I, с. 173).

В исследуемых житиях перцептивные глаголы отмечены и в метафорическом употреблении. Например:

(46) Тогда еще начиналась многоплодная, многотрудная пастырская дъятельность о. Іоанна, въ которой многіе вид'ћли только что-то новое, płзко бьющее, на первый взгляд, въ глаза (СП, с. 278);

(47) Староладожскій Успенскій женскій монастырь С.-П.-Бургск. епархіи... вид'Һлъ немало горестныхъ событій... (ИЕ, с. 247);

(48) ...Кронштадть увидаль немало Петербуржцевъ, пріњхавшихъ помолиться, получить благословеніе о. Іоанна... (СП, с. 280).

В (46) анализируемый глагол используется в сочетании с местоимением что-то, указывающим на существительное широкой се-

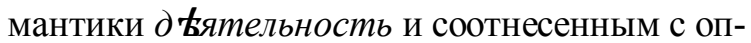
ределениями новое и $p$ tзко бьющее въ глаза, последнее из которых основано на метафорическом переносе. Все это свидетельствует о том, что в данном случае вид $\mathbf{k} m b$ номинирует не процесс восприятия конкретного объекта с помощью органов зрения, а осмысление деятельности Иоанна Кронштадтского, которая не соответствовала сложившимся в обществе представлениям.

В (47) субъект действия, обозначенного глаголом вид $\mathbf{k} m b$, выражен существительным монастырь, а объект - существительным событие. Введение контекстуальных уточнителей немало и горестный представляет собой способ создания контраста между теми периодами, когда монастырь переживал невзгоды, и теми «радостными днями», когда «являлись личности, которыя своею жизнію и дъятельностью 


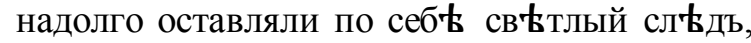
вызывали по себь благодарную память, св Łтлыя воспоминанія» (ИЕ, с. 247). Неодушевленность субъекта и абстрактность объекта исключают возможность обозначения глаголом вид $\mathbf{k} m \mathbf{b}$ зрительного восприятия. В данном случае можно говорить о реализации им значения, близкого современному «переживать, испытывать; знать» (БТСРЯ, с. 130).

В (48) при сохранении признака конкретности объекта действия (петербуржсиы) изменяется характер субъекта действия: позицию субъекта занимает имя собственное Кронштадть, что делает восприятие невозможным и актуализирует значение, близкое к «встречать что-Л., сталкиваться с чем-Л.» (МАC, т. 1, с. 173).

В некоторых случаях глагол вид tmb используется во вставных конструкциях, например:

(49) Сопровождая, какъ мы уже видњли о. Іоанна повсюду, она привлекла на себя вниманіе Кронштадтцевъ... (СП, с. 279).

Анализируемый глагол в форме прошедшего времени и в сочетании с контекстуальным уточнителем уже, не обозначая зрительного восприятия, выражает отсылку к описанным выше событиям из жизни подвижницы (в терминологии И.Р. Гальперина [2007] объективно-авторская ретроспекция).

Глаголы преднамеренного зрительного восприятия представлены лексемами взглянуть, възирать, смотр жть, высматривать, разсматривать, всмотр тться, реализующими и прямые, и переносные значения.

В прямых значениях функционируют все указанные глаголы, номинируя разные «возможности» получения информации с помощью органов зрения. Например:

(50) Затьмъ, взглянувъ къ дубу, у коего стояла Евөимія Моргачева, въ простой крестьянской одежд'... (ИС, с. 179);

(51) Въ начал' 1861 года, выйдя, какъ дылала всякій годъ, взглянуть на Новгородъ, В ъра долго сид'ла, смотря на городъ (ВМ, с. 207);

(52) ...и однажды, когда она пріобщалась, смотрЊвшій изъ алтаря на приступавшихъ къ

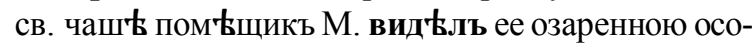
бымъ светомъ (ВМ, с. 201).

Приведенные контексты свидетельствуют о том, что преднамеренное зритель- ное восприятие осуществляется и подвижницами, и людьми из их окружения. Каким бы ни показывал агиограф этот процесс осуществляющимся быстро (взглянувъ) или долго (смотря, смотр ъвшій), глаголы используются в сочетании с предложно-падежными формами существительных или местоимений, что позволяет говорить о грамматической экспликации преднамеренности: глагол управляет формой Вин. п. с предлогом на или формой Дат. п. с предлогом $\kappa b$.

Глагол смотр $\mathbf{k m b}$ употребляется для обозначения восприятия в определенном эмоциональном состоянии:

(53) Находила Ковригина и такихъ, которые с ненавистью смотрфли на добраго пастыря... (CП, c. 279).

Употребление анализируемого глагола в сочетании с уточнителем (с ненавистью) подчеркивает значимость деятельности старицы Параскевы (Ковригиной), которая рассказывала о добрых делах о. Иоанна (Кронштадтского), тем самым убеждая людей в его добрых намерениях и истинной вере, и они «д‡лались ревностн中йшими его почитателями» (СП, с. 279).

Глаголы всмотр $\mathbf{k m b c я , ~ р а з с м а т р и - ~}$ вать, которые обозначают внимательное восприятие, имеющее целью что-то понять, распознать, постигнуть, используются только при описании подвижниц:

(54) ...и надо было им'\$ть осл'大ленныя душевныя очи и окаменълое сердце, чтобы не ощутить чего-то особеннаго, возвышеннаго, всмотр'ввшись въ эту почтенную старицу (СП, с. 282);

(55) Да и нельзя было не прильпиться всъмъ сердцемъ къ этой благочестивой старушк', - съ какой стороны ни разсматривать ее (СП, с. 282).

Из всех глаголов преднамеренного зрительного восприятия переносные значения реализует в изучаемом материале глагол cмотр tmb, который функционирует в составе устойчивого метафорического выражения:

(56) Прикованная къ бол'ззненному ложу, усопшая [Филарета], какъ истинная инокиня, прямо смотрьла в глаза смерти и постоянно готовилась к ней (ИЕиФ, с. 236). 
Использование данного выражения в сочетании с наречием прямо свидетельствует о внутреннем спокойствии подвижницы и приятии ею смерти, что отличает истинно верующих людей.

Глаголы слухового восприятия номинируют в рассматриваемых текстах как непреднамеренное, так и преднамеренное восприятие.

Непреднамеренноеполучение информации с помощью органов слуха обозначают глаголы просльшиать, усльшиать, услыхать.

(57) Но, прослыша про силу молитвъ о. Іоанна, Т. возым Њлъ искреннее желаніе пригласить сего добраго пастыря къ себЊ на квартиру... (СП, с. 281);

(58) Евөимія... услышала пъніе и только тутъ по голосу узнала, что это самъ затворникъ... (ИС, с. 180);

(59) Однажды... когда больная [Евпрасія] лежала в изнеможеніи, вдругъ она услыхала стройное пьніе... (ИЕ, с. 248)

Употребление глагола просльшиать в сочетании с предложно-падежной формой про силу актуализирует в его семантике компонент, связанный с восприятием информации со слов других людей. Сочетание глаголов услыхать и услышать с существительным пение подтверждает реализацию ими прямых значений.

Преднамеренное слуховое восприятие репрезентируется в анализируемом материале лексемами внимать, слушать, выслушать, которые употребляются в прямых значениях.

Глагол внимать представлен в описании подвижницы в сочетании с отрицательной частицей не, например:

(60) ...а сама [Серафима], углубляясь въ умную молитву, уже не внимала никакимъ советамъ и говору (ИС, с. 190).

Использование данного глагола в сочетании с существительными совет и говор, называющими реалии, которые могут быть восприняты с помощью органов чувств, свидетельствует об обозначении им процесса получения информации посредством слуха.

Преимущественно при описании подвижниц и в сочетании с наименованиями реалий, предполагающих восприятие на слух, употреб- ляются также глаголы слушать, выслушать, например:

(61) С какимъ-то особеннымъ религіозновосторженнымъ чувствомъ слушала Ковригина вечерню... (СП, с. 278);

(62) Выслушавъ погребальныя пъсноп'нія, больная [Анна] совершенно ободрилась и даже воодушевилась (СИА, с. 436).

Итак, перцептивные глаголы в анализируемых текстах служат средством описания подвижниц и мирян из их окружения. Из выделенных в зависимости от способа получения информации подгрупп глаголов восприятия в исследуемом материале отмечены подгруппы глаголов с общим значением восприятия, зрительного и слухового восприятия. Глаголы слухового восприятия, как правило, реализуют прямые значения, тогда как глаголы с общим значением восприятия преимущественно используются в переносных значениях. При этом глаголы зрительного восприятия, обнаруживая большой семантический диапазон и широкие сочетаемостные возможности, зафиксированы как в прямых, так и в переносных значениях, отражающих связь восприятия и мыслительных процессов, репрезентация которой представляется значимой для формирования образа подвижницы.

\section{Заключение}

Одними из важнейших при создании образа подвижницы являются языковые единицы с эмотивной и перцептивной семантикой.

Проведенный анализ употребления лексики эмоций позволил сделать ряд выводов: 1) основной функцией эмотивов в агиографическом тексте является характерологическая; специфика ее реализации в рассматриваемых жизнеописаниях определяется преимущественно двумя факторами - характером обозначаемой эмоции и ее интенсивностью; 2) в текстах отмечены так называемые «ключевые характеристики», номинируемые повторяющимися однокоренными лексемами, в большинстве случаев эмотивными; набор данных характеристик задается жанровыми особенностями текстов; выбор в конкретном жизнеописании одной из них свидетельствует о некоторой индивидуализации портретов подвижников; 3) лексика эмоций поддерживает 
развитие сюжета, называя причины важнейших поступков и решений; 4) выбор эмотивных лексем свидетельствует о репрезентации в текстах религиозно-нравственного идеала, черты которого закреплены не только в житийном каноне, но и в русской национальной языковой картине мира.

В результате исследования глаголов восприятия: 1) выявлены значимые для описания подвижниц благочестия перцептивные процессы и особенности их языковой экспликации; 2) определен доминирующий процесс (зрительного восприятия), в ходе которого осуществляется взаимодействие с реальным миром и миром, находящимся за границами реальности и открывающимся подвижницам по воле Господа; 3) установлены процессы, которые не соответствуют представлениям о подвижничестве и потому не репрезентируются в изучаемых текстах, - обоняния, осязания и восприятия на вкус.

Таким образом, для использования перцептивных языковых единиц более значимыми оказываются характеристики, определяемые языковой системой, тогда как эмотивы более зависимы от синтагматических условий - контекста, текста, жанра.

\section{ПРИМЕЧАНИЯ}

${ }^{1}$ Исследование выполнено при финансовой поддержке Российского фонда фундаментальных исследований в рамках научного проекта № 17-34-01009-ОГН «Отражение представлений о нравственном идеале в языке русской оригинальной агиографии XVIII-XX веков».

The reported study was funded by RFBR in the framework of research project no. 17-34-01009ОГН "Reflection of the Moral Ideal Notion in the Language of Russian Original Hagiography of the $18^{\text {th }}-20^{\text {th }}$ Centuries".

${ }^{2}$ Исследование проводилось по изданию 1996 г., которое представляет собой репринт издания: Жизнеописанія отечественныхъ подвижниковъ благочестія 18 и 19 в кков : Сентябрь. М. : Изд. Афон. Рус. Пантелеимонов. монастыря ; Типо-литография И. Ефимова, 1909.

\section{СПИСОК ЛИТЕРАТУРЫ}

Берман Б. И., 1982. Читатель жития (Агиографический канон русского средневековья и тради- ция его восприятия) // Художественный язык средневековья / отв. ред. В. А. Карпушин. М. : Наука. С.159-183.

Буганов А. В., 2009. Отечественные подвижники благочестия и формирование русского национального самосознания // Труды Института российской истории. М. : Наука. Вып. 8. C. $12-25$.

Воловикова М. И., 2004. Представления русских о нравственном идеале. М. : Институт психологии РАН. 312 c.

Гальперин И. Р., 2007. Текст как объект лингвистического исследования. Изд. 5-е, стер. М. : КомКнига. 144 с.

Дмитриева Е. Г., 2011. Функции эмотивной лексики в Повести о Петре и Февронии // Вестник Волгоградского государственного университета. Серия 2, Языкознание. № 2 (14). С. 45-49.

Дмитриева Е. Г., 2018. Религиозно-нравственный идеал в современных агиографических текстах: лингвистическая характеристика // Научный диалог. № 12. C. 64-74. DOI: 10.24224/ 2227-1295-2018-12-64-74.

Дмитриева Е. Г., Сафонова И. А., 2018. Текстовые и языковые средства создания образа подвижника в житиях преподобных старцев // Вестник Волгоградского государственного университета. Серия 2, Языкознание. Т. 17, № 4. C. 27-39. DOI: https://doi.org/10.15688/jvolsu2. 2018.4.3.

Иконникова С., 1962. Идеал нравственный // Философская энциклопедия : в 5 т. М. : Советская энциклопедия. Т. 2. С. 202-204.

Красных В. В., 2016. Словарь и грамматика лингвокультуры. Основы психолингвокультурологии. М. : Гнозис. 496 с.

Радбиль Т. Б., 2010. Основы изучения языкового менталитета. М. : Флинта. 328 с.

Сафонова И. А., 2019. Глаголы восприятия как средство создания образов в Житии Корнилия Переславского // Научный диалог. № 1. С. 122132. DOI: $10.24224 / 2227-1295-2019-1-122-132$.

Семантика древнерусского глагола: синхронно-диахронический аспект : коллект. моногр., 2015 / О. А. Горбань, Е. Г. Дмитриева, М. В. Косова, И. А. Сафонова, Е. В. Терентьева ; отв. ред. Е. М. Шептухина. 2-е изд., доп. М. : Флинта : Наука. 352 c.

Стародубцева Н. А., 2018. Средства выражения нравственного идеала в языке житий русских святителей синодального периода // Научный диалог. № 12. С. 152-165. DOI: 10.24224/22271295-2018-12-152-165.

Творогов О. В., 2005. О «Своде древнерусских житий» // Русская агиография : Исследования, публикации, полемика / ред. : С. А. Семячко 
(отв. ред.), Т. В. Руди. СПб. : Дмитрий Буланин. С. 3-58.

Шаховский В. И., 2009. Язык и эмоции в аспекте лингвокультурологии. Волгоград : Перемена. $170 \mathrm{c}$.

Шмелев А. Д., 2005. Сквозные мотивы русской языковой картины мира // Зализняк Анна. А., Левонтина И. Б., Шмелев А. Д. Ключевые идеи русской языковой картины мира. М. : Языки славянской культуры. С. 452-464.

\section{источники}

БИЗ - Блаженная Ирина Зеленогорская // Жизнеописания отечественных подвижников благочестия 18 и 19 веков : Сентябрь. Козельск : Введен. Оптина Пустынь, 1996. С. 226-230.

$B M$ - ВҺра-молчальница // Жизнеописания отечественных подвижников благочестия 18 и 19 веков : Сентябрь. Козельск : Введен. Оптина Пустынь, 1996. С. 201-207.

ИE - Игуменія Евпраксія // Жизнеописания отечественных подвижников благочестия 18 и 19 веков : Сентябрь. Козельск : Введен. Оптина Пустынь, 1996. С. 247-255.

ИЕиФ - Первоначальницы Мензелинскаго Пророко-Ильинскаго женскаго монастыря игуменіи Евгенія и Филарета // Жизнеописания отечественных подвижников благочестия 18 и 19 веков : Сентябрь. Козельск : Введен. Оптина Пустынь, 1996. С. 231-239.

ИМ - Инокиня Маргарита (Марєа) // Жизнеописания отечественных подвижников благочестия 18 и 19 веков : Сентябрь. Козельск : Введен. Оптина Пустынь, 1996. С. 10-17.

ИС - Сезеновская игуменія Серафима, въ схим'大 Евөимія // Жизнеописания отечественных подвижников благочестия 18 и 19 веков : Сентябрь. Козельск : Введен. Оптина Пустынь, 1996. C. 171-191.

$M E$ - Монахиня Кашинскаго Сptвтенскаго женскаго монастыря Елисавета // Жизнеописания отечественных подвижников благочестия 18 и 19 веков : Сентябрь. Козельск : Введен. Оптина Пустынь, 1996. С. 141-147.

РБТ - Раба Божия Татіана // Жизнеописания отечественных подвижников благочестия 18 и 19 веков : Сентябрь. Козельск : Введен. Оптина Пустынь, 1996. С. 17-19.

СИА - Свияжская схи-игуменія Анна // Жизнеописания отечественных подвижников благочестия 18 и 19 веков : Сентябрь. Козельск : Введен. Оптина Пустынь, 1996. С. 424-438.

СП - Старица Параскева // Жизнеописания отечественных подвижников благочестия 18 и 19 ве- ков : Сентябрь. Козельск : Введен. Оптина Пустынь, 1996. С. 275-285.

\section{СЛОВАРИ}

БТСРЯ - Большой толковый словарь русского языка / Сост. и гл. ред. С. А. Кузнецов. СПб. : «Норинт», 2000. $1536 \mathrm{c}$.

$M A C$ - Словарь русского языка : в 4 т. / под ред. А. П. Евгеньевой. М. : Русский язык, 1985-1988.

СЦСиРЯ - Словарь церковно-славянскаго и русска-

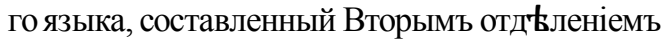
Императорской Академіи наукъ : в 4 т. СанктПетербургъ : ВъТипографіи Императорской Академіи наукъ, 1847.

\section{REFERENCES}

Berman B.I., 1982. Chitatel zhitiya (Agiograficheskiy kanon russkogo srednevekovya i traditsiya ego vospriyatiya) [Hagiographic Text Reader (Hagiographic Canon of Russian Middle Ages and the Tradition of Its Perception)]. KarpushinV.A., ed. Khudozhestvennyy yazyk srednevekovya [Artistic Language of the Middle Ages]. Moscow, Nauka Publ., pp. 159-183.

Buganov A.V., 2009. Otechestvennye podvizhniki blagochestiya i formirovanie russkogo natsionalnogo samosoznaniya [Native Godliness Devotees and the Formation of Russian National Identity]. Trudy Instituta rossiyskoy istorii [Proceedings of The Institute of Russian History]. Moscow, Nauka Publ., iss. 8, pp. $12-25$.

Volovikova M.I., 2004. Predstavleniya russkikh o nravstvennom ideale [Russians' Vision of a Moral Ideal]. Moscow, Institut psikhologii RAN. $312 \mathrm{p}$.

Galperin I.R., 2007. Tekst kak obyekt lingvisticheskogo issledovaniya [Text as an Object of Linguistic Research]. Moscow, KomKniga Publ. 144 p.

Dmitrieva E.G., Akimova E.N., 2011. Funktsii emotivnoy leksiki v Povesti o Petre i Fevronii [Emotive Vocabulary Functions in the Novelette About Petr and Fevroniya]. Vestnik Volgogradskogo gosudarstvennogo universiteta. Seriya 2, Yazykoznanie [Science Journal of Volgograd State University. Linguistics], no. 2 (14), pp. $45-49$.

Dmitrieva E.G., 2018. Religiozno-nravstvennyy ideal v sovremennykh agiograficheskikh tekstakh: lingvisticheskaya kharakteristika [Religious and Moral Ideal in Modern Hagiographic Texts: Linguistic Characteristics]. Nauchnyy dialog 
[Scientific Dialogue], no. 12, pp. 64-74. DOI: 10.24224/2227-1295-2018-12-64-74.

Dmitrieva E.G., Safonova I.A., 2018. Tekstovye i yazykovye sredstva sozdaniya obraza podvizhnika $\mathrm{v}$ zhitiyakh prepodobnykh startsev [Textual and Linguistic Means of Constructing the Venerable Image in Men of Faith Hagiographies]. Vestnik Volgogradskogo gosudarstvennogo universiteta. Seriya 2, Yazykoznanie [Science Journal of Volgograd State University. Linguistics], vol. 17, no. 4, pp. 27-39. DOI: https://doi.org/10.15688/ jvolsu2.2018.4.3.

Ikonnikova S., 1962. Ideal nravstvennyy [Moral Ideal]. Filosofskaya entsiklopediya: $v 5 t$. [Philosophical Encyclopedia. In 5 Vols.]. Moscow, Sovetskaya entsiklopediya Publ., vol. 2, pp. 202-204.

Krasnykh V.V., 2016. Slovar i grammatika lingvokultury. Osnovy psikholingvokulturologii [Dictionary and Grammar of Linguistic Culture. Fundamentals of Psychological Linguistic Culturology]. Moscow, Gnozis Publ. 496 p.

Radbil T.B., 2010. Osnovy izucheniya yazykovogo mentaliteta [Fundamentals of Linguistic Mentality Study]. Moscow, Flinta Publ. 328 p.

Safonova I.A., 2019. Glagoly vospriyatiya kak sredstvo sozdaniya obrazov v Zhitii Korniliya Pereslavskogo [Verbs of Perception as Means of Creating Images in the Life of Korniliy Pereslavsky]. Nauchnyy dialog [Scientific Dialogue], no. 1,pp. 122-132. DOI: 10.24224/22271295-2019-1-122-132.

Gorban O.A., Dmitrieva E.G., Kosova M.V., Safonova I.A., Terentyeva E.V.; Sheptukhina E.M., ed. Semantika drevnerusskogo glagola: sinkhronno-diakhronicheskiy aspect [Semantics of Old Russian Verb: Synchronous and Diachronic Aspect]. Moscow, Flinta Publ., Nauka Publ., 2015. $352 \mathrm{p}$.

Starodubtseva N.A., 2018. Sredstva vyrazheniya nravstvennogo ideala $v$ yazyke zhitiy russkikh svyatiteley sinodalnogo perioda [Means of Expressing Moral Ideal in Language of Hagiographic Texts About Russian Hierarchs of Synodal Period]. Nauchnyy dialog [Scientific Dialogue], no. 12, pp. 152-165. DOI: 10.24224/ 2227-1295-2018-12-152-165.

Tvorogov O.V., 2005. O «Svode drevnerusskikh zhitiy» [On the Collection of Ancient Russian Hagiographic Texts]. Semyachko S.A., Rudi T.V., eds. Russkaya agiografiya: Issledovaniya, publikatsii, polemika [Russian Hagiography: Studies, Publications, Disputes]. Saint Petersburg, Dmitriy Bulanin Publ., pp. 3-58.
Shakhovskiy V.I., 2009. Yazyk i emotsii v aspekte lingvokulturologii [Language and Emotions Within the Framework of Linguistic Culturology]. Volgograd, Peremena. $170 \mathrm{p}$.

Shmelev A.D., 2005. Skvoznye motivy russkoy yazykovoy kartiny mira [Repetitive Motives of the Russian Language Worldview]. Zaliznyak A.A., Levontina I.B., Shmelev A.D., eds. Klyuchevye idei russkoy yazykovoy kartiny mira [Key Ideas of the Russian Language Worldview]. Moscow, Yazyki slavyanskoy kultury Publ., pp. 452-464.

\section{SOURCES}

Blazhennaya Irina Zelenogorskaya [Blessed Irina Zelenogradsaya]. Zhizneopisaniya otechestvennykh podvizhnikov blagochestiya $18 i$ 19 vekov: Sentyabr [Hagiographies of the Native Godliness Devotees of the $18^{\text {th }}-$ $19^{\text {th }}$ Centuries. September]. Kozelsk, Vveden. Optina Pustyn Publ., 1996, pp. 226-230.

Vera-molchalnitsa [Vera the Silentiary]. Zhizneopisaniya otechestvennykh podvizhnikov blagochestiya 18 i 19 vekov: Sentyabr [Hagiographies of the Native Godliness Devotees of the $18^{\text {th }}-19^{\text {th }}$ Centuries. September]. Kozelsk, Vveden. Optina Pustyn Publ., 1996, pp. 201-207.

Igumeniya Evpraksiya [Hegumene Evpraksiya]. Zhizneopisaniya otechestvennykh podvizhnikov blagochestiya 18 i 19 vekov: Sentyabr [Hagiographies of the Native Godliness Devotees of the $18^{\text {th }}-19^{\text {th }}$ Centuries. September]. Kozelsk, Vveden. Optina Pustyn Publ., 1996, pp. 247-255.

Pervonachalnitsy Menzelinskago Proroko-Ilinskago zhenskago monastyrya igumenii Evgeniya i Filareta [Hegumenes Eugenia and Filareta, the Founders of Menzelinsky Prohet-Ilyinsky Nunnery]. Zhizneopisaniya otechestvennykh podvizhnikov blagochestiya 18 i 19 vekov: Sentyabr [Hagiographies of the Native Godliness Devotees of the $18^{\text {th }}-19^{\text {th }}$ Centuries. September]. Kozelsk, Vveden. Optina Pustyn Publ., 1996, pp. 231-239.

Inokinya Margarita (Marfa) [Nun Margarita (Marfa)]. Zhizneopisaniya otechestvennykh podvizhnikov blagochestiya 18 i 19 vekov: Sentyabr [Hagiographies of the Native Godliness Devotees of the $18^{\text {th }}-19^{\text {th }}$ Centuries. September]. Kozelsk, Vveden. Optina Pustyn Publ., 1996, pp. 10-17.

Sezenovskaya igumeniya Serafima, v skhime Evfimiya [Hegumene Seraphima Sezenovskaya]. 
Zhizneopisaniya otechestvennykh podvizhnikov blagochestiya 18 i 19 vekov: Sentyabr [Hagiographies of the Native Godliness Devotees of the $18^{\text {th }}-19^{\text {th }}$ Centuries. September]. Kozelsk, Vveden. Optina Pustyn Publ., 1996, pp. 171-191.

Monakhinya Kashinskago Sretenskago zhenskago monastyrya Elisaveta [Elisaveta, the Nun of Kashinsky Sretensky Nunnery]. Zhizneopisaniya otechestvennykh podvizhnikov blagochestiya 18 i 19 vekov: Sentyabr [Hagiographies of the Native Godliness Devotees of the $18^{\text {th }}-19^{\text {th }}$ Centuries. September]. Kozelsk, Vveden. Optina Pustyn Publ., 1996, pp. 141-147.

Raba Bozhiya Tatiana [Christian Tatiana]. Zhizneopisaniya otechestvennykh podvizhnikov blagochestiya 18 i 19 vekov: Sentyabr [Hagiographies of the Native Godliness Devotees of the $18^{\text {th }}-19^{\text {th }}$ Centuries. September]. Kozelsk, Vveden. Optina Pustyn Publ., 1996, pp. 17-19.

Sviyazhskaya skhi-igumeniya Anna [Hegumene Anna Sviyazhskaya]. Zhizneopisaniya otechestvennykh podvizhnikov blagochestiya 18 i 19 vekov: Sentyabr [Hagiographies of the Native Godliness Devotees of the $18^{\text {th }}$ $19^{\text {th }}$ Centuries. September]. Kozelsk, Vveden. Optina Pustyn Publ., 1996, pp. 424-438.

Staritsa Paraskeva [Elderess Paraskeva]. Zhizneopisaniya otechestvennykh podvizhnikov blagochestiya 18 i 19 vekov: Sentyabr [Hagiographies of the Native Godliness Devotees of the $18^{\text {th }}-19^{\text {th }}$ Centuries. September]. Kozelsk, Vveden. Optina Pustyn Publ., 1996, pp. 275-285.

\section{DICTIONARIES}

Kuznetsov S.A., ed. Bolshoy tolkovyy slovar russkogo yazyka [Great Explanatory Dictionary of the Russian Language]. Saint Petersburg, Norint Publ., 2000. 1536 p.

Evgenyeva A.P., ed. Slovar russkogo yazyka: $v 4 t$. [Dictionary of the Russian Language. In 4 Vols.]. Moscow, Russkiy yazyk Publ., 1985-1988.

Slovar tserkovno-slavyanskago i russkago yazyka, sostavlennyy Vtorym otdeleniem Imperatorskoy Akademii nauk: $v 4 t$. [Dictionary of the Church Slavonic and Russian Language Compiled by the Second Department of the Imperial Academy of Sciences. In 4 Vols.]. Saint Petersburg, V Tipografii ImperatorskoyAkademii nauk, 1847.

\section{Information about the Authors}

Evgeniya G. Dmitrieva, Candidate of Sciences (Philology), Associate Professor, Department of Russian Philology and Journalism, Volgograd State University, Prosp. Universitetsky, 100, 400062 Volgograd, Russia,eg_dmitrieva@volsu.ru, iryas@volsu.ru,https://orcid.org/0000-0001-5117-5677

Irina A. Safonova, Candidate of Sciences (Philology), Associate Professor, Department of Russian Philology and Journalism, Volgograd State University, Prosp. Universitetsky, 100, 400062 Volgograd, Russia, ia_safonova@volsu.ru, iryas@volsu.ru,https://orcid.org/0000-0003-1103-7434

\section{Информация об авторах}

Евгения Геннадьевна Дмитриева, кандидат филологических наук, доцент кафедры русской филологии и журналистики, Волгоградский государственный университет, просп. Университетский, 100, 400062 г. Волгоград, Россия, eg_dmitrieva@volsu.ru, iryas@volsu.ru, https://orcid.org/0000-0001-5117-5677

Ирина Александровна Сафонова, кандидат филологических наук, доцент кафедры русской филологии и журналистики, Волгоградский государственный университет, просп. Университетский, 100, 400062 г. Волгоград, Россия, ia_safonova@volsu.ru, iryas@volsu.ru, https://orcid.org/0000-0003-1103-7434 